\title{
ANALISIS SOSIOLOGIS YURIDIS TERHADAP PEMIDANAAN ANAK DI KOTA PALU
}

\author{
M . Arma Amin ${ }^{1}$, Akhdiari Harpa $\mathrm{Dj}^{2}$ Fadli Yasser Arafat $\mathrm{J}^{3}$ \\ Email: akhdiari.harpa@gmail.com
}

\begin{abstract}
ABSTRAK
Permasalahan yang diteliti adalah pemidanaan anak di kota palu di tinjau dari perspektif sosiologis yuridis dan gambaran aspek kemanfaatan sistem peradilan pidana anak saat ini. Metode penelitian menggunakan penelitian hukum normatif dan emipiris yang menggunakan bahan hukum primer dan bahan hukum sekunder yang pengolahan bahan hukum pada dasarnya serangkaian aktivitas untuk mengadakan sistematisasi atau klasifikasi atas bahan hukum tertulis serta mengadakan wawancara kepada instansi terkait untuk mempermudah kegiatan analisis terhadap penulisan. Penilitian ini bertujuan untuk mengetahui pemidanaan anak di Indonesia utamanya di kota Palu dan untuk mengetahui konsep pemidanaan yang bertujuan untuk memberikan perlindungan demi tercapainya kesejahteraan anak, maka keriteria/standar berat ringannya pemberian sanksi bukan hanya dilihat/diukur secara kuantitatif, melainkan lebih didasarkan kepada pertimbangan kualitatif. Penilitian ini menunjukkan sistem pemidanaan anak saat ini dalam Sistem Peradilan Pidana Anak dapat memberikan manfaat serta pemulihan terhadap anak sebagai pelaku tindak pidana, dan hasilnya bahwa Sistem Peradilan Pidana Anak saat ini lebih memberikan kebebasan dalam penyelesaian sengketa anak diluar pengadilan melaui diversi dan restorative justice dan berdasarkan pengamatan dan data yang telah kami kumpulkan didapatkan pula hasil bahwa pemberian hukuman terhadap anak hendaknya dijadikan sebagai sarana pembinaan dan merehabilitasi anak nakal tersebut untuk melindunginya dari stigma buruk terhadapnya, untuk itu negara harus tampil sebagai pelindung dan teman bagi anak bukannya sebagai pelaksana pembalasan masyarakat yang marah atas perbuatan yang dilakukan oleh anak. Melalui penilitian ini, diharapkan agar pemidanaan anak kedepannya dapat segera diambil lankah-langkah antara lain dalam hukum pidana nasional memuat ketentuan yang jelas, tegas dan berimbang mengenai pemidanaan anak atau upaya melakukan peninjauan pembentukan kembali ketentuan hukum pidana mengenai pemidanaan anak yang sesuai dengan nilai-nilai sentralsosio-politik, sosio-filosofik, dan nilai-nilai sosio kultural masyarakat Indonesia utamanya di Kota Palu, demi mengurangi angka kejahatan yang dilakukan oleh anak .
\end{abstract}

Kata Kunci: Pemidanaan, Anak Nakal, Perlindungan dan Kesejahteraan Anak.

\section{ABSTRACT}

\section{M . Arma Amin, "Analysis Of Juridical Sociology To Child Crime In Palu City", under the supervisious of Akhdiari Harpa Dj and Fadli Yasser Arafat $j$}

The problem of this research was the sentence of children in Palu city viewed by perspective juridical sociology and the aspect of expediency of the criminal justice system of child at this time. The method of this research was normative and empirical legal research using primary and secondary law materials which processing of legal material is basically a series of activities to organize systematization or clarification on written legal material and conduct interview to related institution to facilitate analysis of writing activity. This research aims to find out the sentence of children in Indonesia primarily in Palu city and to know the concept of sentence that aims to provide protection for the achievement of children welfare, the criteria / standard of 
sanction is not only measured quantitatively, but rather based on qualitative considerations. The research also shows whether the current child crime system in the juvenile justice system can provide benefits and remedies to children as perpetrators of criminal acts, and the result is that the current criminal justice system provides more freedom in settling disputes outside the court through diversion and restorative justice and based on the observations and the data collected got the result that the sentence of children should be used as a means of fostering and rehabilitating the naughty child to protect them from bad stigma, therefore country should be as a protector and friend for the children rather than as the executor the retaliation of the people who are indignant over of the child acts. Through this research, it is expected that the future criminal sentence can be immediately taken such as in the national criminal law contains clear, strict and balanced provisions concerning the crime of children or an attempt to review the re-establishment of criminal law provisions concerning the sentence of children in accordance with the value of central socio-political, socio-philosophical, and the value of sociocultural society in Indonesia primarily in Palu city in order to reduce the number of crimes committed by child.

\section{Keywords: Sentence of the Children, Child Mischief, Protection and Welfare of Child}

\section{PENDAHULUAN}

Peradilan Pidana Anak merupakan suatu peradilan yang khusus menangani perkara pidana anak. Penyidik anak, penuntut umum anak, hakim anak, petugas pemasyarakan anak merupakan satu kesatuan yang termasuk dalam suatu sistem yang disebut dengan Sistem Peradilan Pidana Anak (Juvenile Justice System), bertujuan untuk menanggulangi kenakalan anak, sekaligus juga diharapkan memberikan perlindungan kepada anak yang mengalami masalah hukum. Proses peradilan pidana anak mulai dari tahap penyidikan,

penuntutan, pengadilan, dan dalam menjalankan putusan pengadilan di Lembaga Pemasyarakatan Anak wajib dilakukan oleh pejabat-pejabat yang terdidik khusus atau setidaknya mengetahui tentang masalah anak nakal. Perlakuan selama proses Peradilan Pidana Anak harus memperhatikan prinsip-prinsip perlindungan anak dan tetap menjunjung tinggi harkat dan martabat anak tanpa mengabaikan terlaksananya keadilan, dan bukan membuat nilai kemanusiaan anak menjadi rendah. Untuk itu diusahakan agar penegak hukum tidak hanya ahli dalam bidang ilmu hukum akan tetapi terutama jujur dan

bijaksana serta mempunyai pandangan yang luas dan mendalam tentang kelemahan-kelemahan dan kekuatan-kekuatan manusia serta masyarakatnya.

Pemidanaan anak dalam Deklarasi Wina tahun 1993 yang dihasilkan Konvensi Dunia tentang Hak Asasi Manusia, kembali menemukan prinsip First Call for Children yang menekankan upayaupaya nasional dan internasional untuk memajukan hak-hak anak atas survival protection, development and participation. Sebagai bentuk kepedulian negara terhadap generasi penerus bangsa, sampai sekarang pemerintah Indonesia telah meratifikasi Konvensi Hak Anak melalui Keppres No 36 tahun 1990, Undang-Undang No 39 tahun 1999 tentang Hak Asasi manusia, Undang-Undang Nomor 17 Tahun 2016 perubahan kedua atas Undang-Undang No 23 tahun 2002 tentang Perlindungan Anak, dan Undang-Undang No. 11 tahun 2012 tentang Sistem Peradilan Pidana Anak yang mencabut UndangUndang No 3 tahun 1997 tentang Pengadilan Pidana Anak serta peraturan peruntang-undangan lainnya. Semua istrumen hukum nasional ini dimaksudkan untuk memberikan jaminan perlindungan hak-hak anak secara lebih kuat ketika mereka berhadapan dengan hukum dan harus menjalani proses peradilan. Undang-Undang Sistem Peradilan Pidana Anak antara lain ditujukan untuk memperbaiki hukum pidana anak di Indonesia agar putusan pengadilan anak menjadi lebih baik dan berkualitas dilihat dari aspek kemanfaatannya, karena putusan hakim akan mempengaruhi kehidupan anak dimasa mendatang.

Sistem Peradilan Pidana Anak tidak hanya ditekankan pada penjatuhan sanksi pidana bagi anak pelaku tindak pidana, melainkan juga difokuskan pada pemikiran bahwa penjatuhan sanksi dimaksuckkan sebagai sarana 
mewujudkan perlindungan anak dan kesejahteraan anak pelaku tindak pidana tersebut. Hal demikian sejalan dengan tujuan penyelenggaraan Sistem Peradilan Pidana Anak yang dikehendaki oleh dunia internasional yang menggunakan pendekatan sistem hukum yang lebih humanis yang lebih mengutamakan pendekatan keadilan restoratif (restorative justice).

Sistem yang berlaku untuk pemberian upaya perlindungan anak dan mensejahterahkan anak dalam tindak kejahatan atau tindak pidana, sering juga didapatkan tidak efektif atau tidak berjalan lurus atau pada hakekatnya penerapan sistem pembinaanpun belum mencapai sasarannya. Disinilah tugas dari pemerintah memberikan pemahaman dan juga memberikan pembinaan dan rehabilitasi yang baik agar anak tidak melakukan tindak pidana. Disisi lain apabila pemerintah mengembalikan anak tersebut kepada orang tuanya padahal sianak melakukan tindak pidana disinilah sistem itu gagal, karena anak yang dikembalikan kepada orang tuanya merasa dilindungi dengan keadaan ini, bisa jadi sianak rentan akan mengulangi perbuatan pidana kembali. Dan kita harus pula memikirkan juga korban dari kejahatan yang dilakukan oleh anak ini, sehingga mesti ada suatu sistem yang baik didalam keadilan yang berlaku di Indonesia. Disinilah perlu ada perhatian yang khusus dan terobosan yang baik untuk perkembangan sistem penjatuhan sanksi pada anak dibawa umur ini guna mengurangi angka kejahatan yang dilakukan oleh anak.

Dalam hal ini perlu diperhatikan perlindungan hukum terhadap anak dan peradilan pidana anak. Perlindungan hukum dalam hal ini mengandung pengertian perlindungan anak berdasarkan ketentuan hukum yang berlaku (yang mengatur tentang Peradilan Pidana Anak). Peradilan pidana anak 
mengandung pengertian proses pemeriksaan pidana anak, mulai dari tahap penyidikan, penuntutan, persidangan, dan pemasyarakan. Jadi penelitian ini ingin mengungkapkan keberadaan peraturan tentang Undang-Undang Nomor 11 Tahun 2012 tentang Sistem Peradilan Pidana Anak kaitannya dengan pemidanaan terhadap anak. Baik penerapanya dalam menangani persoalan kasus-kasus kenakalan anak dan mengetahui hambatan-hambatan dan usaha penanggulangannya.

Berdasarkan latar belakang masalah sebagaimana yang telah diuraikan sebelumnya, maka rumusan masalah penelitian ini dapat disusun sebagai berikut: (1) Bagaimanakah pemidanaan anak di kota Palu di tinjau dari perspektif sosiologis yuridis? (2) Apakah sistem peradilan pidana anak saat ini telah menggambarkan aspek kemanfaatan?.

\section{METODE PENELITIAN}

Tipe penelitian yang digunakan oleh peneliti adalah penelitian hukum empiris.

Penelitian hukum empiris adalah suatu metode penelitian hukum yang berfungsi untuk melihat hukum dalam artian nyata dan meneliti bagaimana bekerjanya hukum di lingkungan masyarakat.

Data yang dgunakan dalam penelitian ini adalah, data perimer dan data sekunder. Data perimer diperoleh dari sumber informasi secara langsung dari sumber aslinya berupa pengamatan dan hasil wawancara. Sedangkan data sekunder diperoleh dari hasil penelusuran bahan pustaka (literature) dokumen dari instansi terkait, dan dari jurnal ilmiah.

Metode pengumpulan data yang digunakan dalam penelitian ini meliputi pengamatan kepustakaan dan wawancara.

Data yang diperoleh dari penelitian ini

dianalisis secara kualitatif, kemudian diidentifikasi serta dilakukan kategorisasi. Analisis kualitatif yaitu metode analisis yang pada dasarnya mempergunakan pemikiran logis, analisis dengan logika, dengan induksi, deduksi, analogi/interprestasi, komparasi dan sejenis itu. Metode berpikir yang dipergunakan adalah metode dedukatif, yaitu berdasarkan dasar-dasar pengetahuan yang bersifat umum untuk mengkaji persoalan-persoalan yang bersifat khusus. Dari hasil analisis tersebut kemudian akan ditarik kesimpulan sebagai jawaban atas permasalah yang ada.

\section{HASIL DAN PEMBAHASAN Pengertian Anak dan Pendidikan Anak}

Secara umum dikatakan anak adalah seorang yang dilahirkan dari perkawinan antara seorang perempuan dengan seorang laki-laki dengan tidak menyangkut bahwa seseorang yang dilahirkan oleh wanita meskipun tidak pernah melakukan pernikahan tetap dikatakan anak, anak juga merupakan cikal bakal lahirnya suatu generasi baru yang merupakan penerus cita-cita perjuangan bangsa dan sumber daya manusia bagi pembangunan Nasional. Anak adalah asset bangsa. Masa depan bangsa dan Negara dimasa yang akan datang berada ditangan anak sekarang. Semakin baik keperibadian anak sekarang maka semakin baik pula kehidupan masa depan bangsa. Begitu pula sebaliknya, Apabila keperibadian anak tersebut buruk maka akan bobrok pula kehidupan bangsa yang akan datang.

Sekolah telah menyediakan serangkaian materi untuk mendidik seorang anak hingga dewasa termasuk perkembangan dirinya.

Namun, tanggung jawab pendidikan bukan semata-mata menjadi tanggung jawab sekolah. Kunci menuju pendidikan yang baik adalah keterlibatan orang dewasa yaitu orang-tua yang penuh perhatian. 
Jika orang-tua terlibat langsung dalam pendidikan anak-anak di sekolah, maka prestasi anak tersebut akan meningkat. Setiap siswa yang berprestasi dan berhasil menamatkan pendidikan dengan hasil baik selalu memiliki orang-tua yang selalu bersikap mendukung. Sebagai orang-tua, Anda dapat menghindari banyak problem dan kekhawatiran atas pendidikan anak Anda dengan mengingat bahwa kerja sama yang sukses dibangun di atas komunikasi yang baik. Kerja sama yang baik dengan para pendidik di sekolah juga dapat membantu melindungi anak.

\section{Hak-hak Anak Dalam Hukum Pidana.}

Wujud dari suatu keadilan adalah dimana pelaksanaan hak dan kewajiban seimbang. Hak dan kewajiban bagi anak yang melakukan tindak pidana perlu mendapat bantuan dan perlindungan agar seimbang dan manusiawi. Kewajiban bagi anak harus diperlukan sesuai situasi, kondisi mental dan fisik, keadaan sosial dengan kemampuannya pada usia tertentu.

\section{Tinjauan Umum Tentang Pemidanaan Dan Tujuan Pemidanaan.}

Pemidanaan dalam hukum pidana mencakup dua hal, yaitu pertama pembalasan sebagai pengimbangan atas dasar tingkat kesalahan si pelaku dan yang kedua tujuan pemidanaan berupa memelihara solidaritas masyarakat, diarahkan untuk memelihara dan mempertahankan kesatuan masyarakat.

Adapun pemikiran mengenai tujuan pemidanaan yang dianut dewasa ini, sebenarnya bukan suatu pemikiran yang baru, melahirkan sedikit atau banyak telah mendapat pengaruh

dari para penulis abad yang lalu telah mengeluarkan pendapat mereka tentang dasar pembenaran atau rechtvaardigings ground dari suatu pemidanaan. Baik yang melihat pemidanaan semata-mata sebagai pemidanaan saja, maupun yang mengaitkan pemidanaan dengan tujuan yang ingin dicapai dengan pemidanaannya sendiri.

\section{Pemidanaan Terhadap Anak.}

Undang-Undang Sistem Peradilan Pidana lahir sebab Undang-Undang Pengadilan Anak sebelumnya tidak lagi sesuai dengan kebutuhan hukum dalam masyarakat dan belum secara

komprehensip memberikan perlindungan khusus kepada anak yang berkonflik dengan hukum. Sehingga perlu adanya sesuatu perubahan paradigma dalam penanganan anak yang berhadapan dengan hukum, antara lain didasarkan pada peran dan tugas masyarakat, pemerintah, dan lembaga negara lainnya yang berkewajiban dan bertanggungjawab untuk meningkatkan kesejahteraan anak serta memberikan perlindungan khusus kepada anak yang berkonflik dengan hukum. Disamping itu terdapat kenyataan bahwa tingkat tindak pidana yang dilakukan oleh anak masih tinggi dengan angka residifis anak yang tidak mengalami penurunan. Dan lebih jauh lagi, pendekatan pengadilan anak dirasa terlalu logistik serta pengadilan lebih banyak menggunakan pendekatan pemenjaran daripada sanksi lain bagi anak.

Terdapat tiga substansi baru dalam Undang-Undang Sistem Peradilan Pidana Anak yang berhubungan dengan pemidanaan anak, antara lain :

\section{a. Keadilan Restoratif (Restorative Justice)}

b. Diversi

c. Ancaman Pidana Minimum khusus dan

Denda dalam Pemidanaan Dihapuskan. Sama seperti pengaturan mengenai

pemidanaan bagi anak berhadapan hukum dalam peraturan perundang-undangan yang terdahulu, dalam undang-undang Sistem Peradilan Pidana, anak berhadapan hukum dapat dikenai baik pidana maupun tindakan. 
Antisipasi atas kejahatan tersebut diantaranya dengan mengfungsikan instrument hukum (pidana) secara efektif melalui penegakan hukum (law enforcement). Melalui instrument hukum, diupayakan perilaku yang melanggar hukum dapat ditanggulangi secara preventif maupun refresif. Mengajukan ke depan sidang peradilan dan selanjutnya menjatuhkan pidana bagi anggota masyarakat yang terbukti melakukan pidana, merupakan tindakan yang refresif.

Lahirnya penjatuhan pidana dan pemidanaan bukan muncul begitu saja, melainkan melalui proses peradilan. Dengan demikian, melalui instrument hukum pidana, diupayakan perilaku yang melanggar hukum dapat ditanggulangi secara preventif maupun represif. Jadi, dalam sistem hukum kita asas praduga tak bersalah (presumption of ennocence), pidana sebagai reaksi atas delik yang dijatuhkan harus berdasarkan pada vonis hakim melalui sidang pengadilan atas terbuktinya perbuatan pidana yang dilakukan. Apabila tidak terbukti bersalah maka tersangka

dibebaskan. Jadi, putusan pengadilan merupakan tongkak yang penting bagi cerminan keadilan, termasuk putusan pengadilan yang berupa penjatuhan pidana dan pemidanaan.

a. Syarat-Syarat Pemidanaan Terhadap Anak

Syarat pemidanaan terhadap anak tidak

terlepas dari upaya pembinaan dan perlindungan terhadap anak itu sendiri. Dalam teori "Von Psychologische Zwang", disebutkan

bahwa suatu ancaman pidana pada hakekatnya mempunyai suatu akibat psikologis yang menghendaki orang untuk hidup tertib. Hal ini, disebabkan oleh karena pidana itu merupakan susuatu yang dirasakan tidak mengenakkan bagi terpidana. Dengan demikian ancaman suatu sanksi pidana akan merupakan pencegah psikis bagi seorang anak dari melakukan suatu perbuatan pidana. Berdasarkan hal ini maka syarat-syarat atau ukuran-ukuran bagi suatu pemidanaan khususnya terhadap anak nakal menghendaki dipilihnya syarat baik yang menyangkut segi perbuatannya, maupun yang menyangkut segi orang atau perilakunya.

Dari segi perbuatan, maka syarat berupa asas "legalitas" merupakan hal yang fundamental dan menentukan suatu pemidanaan. Pada prinsipnya asas ini menghendaki bahwa untuk dapat memidana seorang anak yang telah melakukan perbuatan pidana, disamping itu perbuatan itu telah ditentukan terlebih dahulu dalam suatu

peraturan perundang-undangan sebagai perbuatan yang dilarang maka ketentuan dan batas pasti mengenai pidana yang dapat dijatuhkan harus pula tergantung secara tegas dalam peraturan perundangan tersebut. Asas ini dalam bahasa Latin dikenal dengan istilah "Nullum Delictum Nulla Poena Sine Praevialege". Artinya tidak ada delik, tidak ada pidana tanpa peraturan terlebih dahulu.

Adapaun dari segi pelaku, maka asas kelasahan pelaku merupakan unsur yang harus dipenuhi agar pelaku anak dapat dijatuhi pidana. Karena hanya orang yang benar-benar bersalahlah yang dapat dijatuhi pidana (asas tiada pidana tanpa kesalahan atau Geen Straf Zonder Schuld). Untuk dapat dikatakan seorang pelaku pidana itu mempunyai kesalahan. Menurut Simons, harus ada keadaan psychic tertentupada pelaku dan adapula hubungan antara keadaan tersebut dengan perbuatan yang dilakukan sedemikian rupa, sehingga orang dapat dicela karena melakukan perbuatan tadi. Jadi Berdasarkan uraian diatas dapat disimpulkan, bahwa untuk dapat menjatuhkan pidana terhadap anak pelaku pidana ialah perbuatan tersebut harus memenuhi rumusan delik dalam Undang-Undang Hukum Pidana yang telah ditentukan sebelumnya (asas legalitas). Disamping itu, disyaratkan juga adanya keyakinan hakim bahwa perbuatan tersebut benar-benar dilakukan oleh yang bersalah (asas Green Straf Zonder Schuld).

b. Tujuan Pemidanaan Terhadap Anak Filosofi pemidanaan terhadap anak sebagai 
pelaku perbuatan pidana diarahkan pada aspek pemenuhan kesejahteraan dan melakukan aspek probation. Maksunya, pemidanaan terhadap anak harus diutamakan pada jenis yang tidak menghilangkan masa depan anak yang bersangkutan. Adapun tujuan dan dasar pemekiran untuk mengutamakan kesejahteraan anak ditegaskan pula dalam SMR-JJ 1985 (the Baijing Rules). Dalam Rule 5.1 mengenai Aims Of Juvenile Justice di tegaskan :

" the juvenile justice system shall emphasize he well being of the juvenile and shall ensure that any reaction to juvenile offender and the offence".

Artinya: "sistem pengadilan anak harus menekankan kesejahteraan anak dan harus memastikan bahwa reaksi apapun untuk anak pelaku dan pelanggaran”

Berdasarkan tujuan yang ini dicapai dalam suatu pemidanaan dalam kaitannya dengan anak nakal, maka pada dasarnya tujuan pemidanaan terhadap anak nakal harus diarahkan kepada perlindungan masyarakat dari kejahatan serta keseimbangan dan keselarasan

hidup dalam masyarakat dengan memperhatikan kepentingan-kepentingan masyarakat atau Negara, korban dan pelaku. Dalam kaitannya dengan pemidanaan ini, Barda Nawawi Arief berpendapat bahwa tujuan pemidanaan mengandung dua aspek, yaitu : a. aspek perlindungan masyarakat terhadap

tindak pidana, dan

b. aspek perlindungan terhadap individu atau pelaku tindak pidana.

Kedua aspek pokok ini mempunyai tujuan masing-masing. Aspek pokok pertama meliputi tujuan : mencegah, mengurangi, atau mengendalikan perbuatan pidana serta memulihkan atau mengendalikan perbuatan pidana serta memulihkan keseimbangan masyarakat yang perwujudannya sering dikemukakan dalam berbagai ungkapan antara lain : menyelesaikan konflik, menimbulkan rasa aman, memperbaiki kerugian atau kerusakan yang timbul, menghilangkan noda-noda yang ditimbulkan, memperkuat kembali nilai-nilai yang hidup dalam masyarakat. Aspek pokok yang kedua bertujuan : memperbaiki si pelaku yang sering dikemukanan dalam berbagai ungkapan seperti : melakukan rehabilitasi dan memasyarakatkan kembali si pelaku untuk membebaskan si pelaku, mempengaruhi tingkah laku si pelaku untuk tertib atau patuh kepada hukum, melindungi si pelaku dari pengenaan sanksi atau pembalasan yang sewenang-wenang diluar hukum.

a. Dari uraian di atas mengenai tujuan pemidanaan terhadap anak nakal ini dapat diambil kesimpulan, bahwa pada dasarnya pemidanaan terhadap anak nakal harus artikan sebagai proses pembinaan keasadaran anak untuk memahami masa depan anak yang lebih baik dan ditunjukan

dalam rangka untuk : menjamin pertembuhan dan perkembangan anak secara wajar, baik secara rohani, jasmani maupun sosial (Pasal 1 sub 1a UU No. 4 Tahun 1979 tentang Kesejahteraan Anak);

b. memberikan hak anak atas kesejahteraan berdasarkan kasih sayang untuk tumbuh dan berkembangan secara wajar (Pasal 2 ayat 1 UU No. 4 Tahun 1979 tentang Kesejahteraan Anak); dan

c. menolong anak guna mengatasi hambatan yang terjadi dalam masa pertembuhan dan perkembangannya (Pasal 6 ayat 1 UU No. 4 Tahun 1979 tentang Kesejahteraan Anak).

Dalamrangkapengawasandan

pengamatan terhadap putusan pengadilan pidana terhadap terpidana yang dijatuhi pidana perampasan kemerdekan (pidana penjara), maka pengawasan dan pengamatan termaksud dilakukan oleh seorang hakim yang ditunjuk dalam dalam lingkup pengadilan yang menjadi cakupan peradilan umum. Hakim pengawas dan pengamat termaksud dipilih olek Ketua Pengadilan untuk masa waktu dua tahun. Pengawasan yang dilakukan tersebut guna

memperoleh kepastian bahwa putusan 
pengadilan dilaksanakan sebagaimana mestinya. Adapun pengamatan dilakukan dalam rangka mengumpulkan bahan penelitian guna ketetapan yang bermanfaat bagi pemidanaan. Pengamatan juga dilakukan setelah narapidana selesai menjalani pidananya.

Berdasarkan hasil penelitian di Pengadilan Negeri Palu melalui wawancara kepada Hakim Khusus Anak oleh ibu Ernawati,S.H.,M.H mengungkapkan bahwa pengawasan khusus yang dilakukan Hakim Pengawas dan Pengamat (KIMWASMAT) terhadap putusan pengadilan terhadap anak nakal yang dijatuhi pidana penjara terlihat belum efektif dan belum terlihat nyata.

Peranan Kimwasmat dalam sistem peradilan pidana anak sampai saat ini belum terlihat nyata. Karena itu, diperlukan mekanisme yang dapat ditempuh anak selama dalam lembaga pembinaan untuk menyampaikan pengaduan secara bebas kepada lembaga yang berwenang dengan jaminan perlindungan atas apa yang mereka sampaikan. Sejalan dengan itu maka keterlibatan Lembaga Swadaya Masyarakat (LSM), pemerhati masalah anak serta peran relawan bisa menjadi jembatan dalam pelaksanaan evaluasi terhadap kinerja aparat dalam sistem peradilan.

\section{Konsep Pemidanaan Dalam Pembaharuan Sistem Peradilan Pidana Anak.}

Pemikiran bersifat prospektif dalam arti konsep masa mendatang dalam pembaharuan sistem peradilan anak yang mengacu pada Rancangan Kita Undang-Undang Hukum Pidana dan Sistem Peradilan Pidana Anak serta

sejumlah peraturan perundang-undangan tentang anak adalah sistem peradilan pidana anak dengan welfare approach (pendekatan Kesejahteraan). Adapun yang dimaksud kesejahteraan adalah kesejateraan anak sebagaimana yang dimaksud oleh Undang-Undang No.4 tahun 1997 tentang kesejateraan Anak Pasal 1 huruf a, yaitu suatu tata kehidupan dan penghidupan anak yang dapat menjamin rohani, jasmani maupun sosial. Pendekatan yang demikian, juga sejalan dengan pendekatan sejumlah negara di Eropa yang

memiliki peraturan perundang-undangan tentang juvenile justice, secara umum telah menggunakan pendekatan kesejahteraan. Dengan pendekatan ini pelanggar hukum usia muda dapat mungkin dijauhkan dari proses

penghukuman oleh sistem peradilan pidana, serta segala tindakan yang akan diambil oleh negara berkaitan dengan pelanggaran yang dilakukan oleh anak tersebut sedapat mungkin mengedepankan the best interes of child.

Demikian halnya dengan Konvensi Hak Anak yang menyatakan bahwa tindakan hukum yang menyatakan anak berusia dibahah 18 (delapan belas) tahun, diasumsikan tidak dapat peneh bertanggung jawab atas tindakannya.

Berkaitan dengan batas usia anak pertanggungjawaban kriminal, yaitu batas usia pelaku pelanggaran hukum dapat dimintai pertanggungjawaban atas tindakannya melalui proses peradilan pidana, dalam hal Juvenile Delinquency. Namun pada prinsipnya, semakin rendah usia pertanggungjawaban kriminal maka semakin tidak sensitif negara tersebut terhadap kepentingan terbaik anak. Kenyataannya terdapat 5 (lima) macam pendekatan yang biasa digunakan oleh negara-negara di eropa dalam menangani pelaku pelanggaran hukum usia anak, yaitu :

1. Pendekatan yang murni mengedepankan kesejahteraan anak;

2. Pendekatan kesejahteraan dengan intervensi hukum;

3. Pendekatan dengan menggunakan / berpatokan pada sistem peradilan pidana semata;

4. Pendekatan edukatif dalam pemberian hukuman;

5. Pendekatan hukuman yang murni bersifat yang murni bersifat retributif. ${ }^{17}$

Adanya kelima bentuk pendekatan tersebut diatas, tidak terlepas dari pertentangan antara 2 (dua) pendekatan dominan dalam menangani juvenile delinquency, yaitu pendekatan 
kesejahteraan dengan pendekatan keadilan (pendekatan yang lebih tua) dan juga mencerminkan perubahan/dinamika pemikiran masyarakat dalam memberikan reaksi terhadap pelaku pelanggaran hukum usia anak.. 18

Sistem Peradilan Pidana Anak menurut the Beijing Rules dimuat pada Pasal 5 bertujuan mengutamakan pendekatan keadilan restoratif yang meliputi :

a. Penyidikan dan penuntutan pidana anak dilaksanakan sesuai dengan ketentun undang-undang, kecuali ditentukan lain dalm undang-undang ini;

b. Pemeriksaan anak di sidang pengadilan yang diadili dalam sidang anak yang berada dilingkungan peradilan umum; dan

c. Pada tahap penyidikan maupun penuntutan wajib diupayakan diversi. Sedangkan Sistem peradilan Pidana Anak menurut Konvensi Hak Anak (Pasal1, Pasal 2, Pasal

3. Pasal 12 dan pasal 13) berasaskan:

a. perlindungan;

b. nondiskriminasi;

c. kepentingan terbaik bagi anak;

d. penghargaan terhadap pendapat anak;

e. kelangsungan hidup dan tumbuh kembang anak ;

f. pembinaan dan pembimbingan anak, proporsional; dan

g. perampasan kemerdekaan sebagai upaya terakhir.

\section{Perbandingan Konsep Pemidanaan Anak di Berbagai Negara.}

\section{Belanda.}

Di Belanda telah menerapkan pemidanaan

anak yang berbasis restoratif yang mengakibatkan sebagaian besar perkara tindak pidana yang pelakunya adalah anak

diselesaikan diluar pengadilan dengan cara diversi. Hal tersebut merupakan suatu konsekwensi logis dari penerapan keadilan restoratif yang sudah dapat dilakukan sejak tahap penyidikan, prinsip ini disebut juga prinsip kemanfaatan (expediency principle). Salah satu bentuk diversi di Belanda adalah dengan sanksi kerja sosial yang diberikan pada anak-anak yang dapat menjadi suatu media pembelajaran bagi anak.

\section{Inggris}

Pernyataan bahwa perampasan kebebasan

harus dijadikan upaya terakhir (last resort) dalam pemidanaan merupakan pernyataan bahwa merupakan pernyataan yang disepakati bersama di seluruh dunia., tidak terkecuali Inggris. Pada tahun 1990-an sebelum Inggris menerapkan hal tersebut, terdapat kenaikan drastis terhadap jumlah tahanan anak. Namun pada tahun 1999 hingga 2009 setelah konsep tersebut diterapkan, terjadi pengurangan perhadap jumlah tahanan tersebut hingga $35 \%$. Hal tersebut menentang asumsi yang menyatakan bahwa penerapan suatu hukuman yang ringan pasti menyebabkan kenaikan jumlah kejahatan. ${ }^{20}$ Kebijakan legeslatif di Inggris telah mengakomodir prinsip keadilan restoratif, misalnya dalam pemberian sanksi, Inggris cenderung mengenakan rehabilitasi dan restitusi kepada anak yang melakukan tindak pidana., bukan lagi mengenakan hukuman badan.

3. Italia.

Italia memiliki suatu pemidanaan bagi anak yang juga bertujuan menjadikan perampasan kebebasan anak sebagai upaya terakhir yang dapat dijatuhkan terhadap anak. 
Misalnya dalam hal terjadi suatu tindak pidana yang hanya mengakibatkan kerugian kecil tidak selalu diperlakukan sebagai tindak pidana. Terhadap hal tersebut Italia memiliki cara penyelesaian tersendiri berupa pengampunan hukum dari hakim anak yang mana memiliki kemiripan konsep dengan diversi dalam pemidanaan anak.

Sedangkan untuk perkara yang dikualifikasikan sebagai tindak pidana oleh Italia diatur dalam aturan peradilan pidana anak yang telah diperkenalkan sejak tahun tahun 1988. Peraturan tersebut mengakibatknan pergeseran paradigma pemidanaan yang awalnya merupakan retributif murni menuju suatu konsepsi baru dalam sistem peradilan pidana anak, yakni keadilan retributif. Upaya keadilan retributif mendapat lebih banyak perhatian sebab mediasi antara korban dan pelaku dapat diaplikasikan di tiap-tiap tahapan peradilan pidan anak.

\section{UCAPAN TERIMAH KASI}

Terimah kasi kepada seluruh instansi yang telah membantu dalam penyelesaian tugas akhir ini. Ucapan terimah kasi terkhusus kepada yang sangat saya hormati, Dr.Hj.Kartini Malarangan, S.H.,M.H selaku Ketua Pembimbing dan Dr.Syachdin, S.H., M.H selaku Pembimbing Anggota atas bimbingannya yang telah meluangkan waktu dan pikiran, mengarahkan, memotivasi serta memberikan ide-ide kreatif, walaupun keduanya sangat sibuk dengan aktivitasnya, tetapi masih menyempatkan waktunya untuk membimbing penulis.

\section{KESIMPULAN DAN REKOMENDASI A. Kesimpulan}

1. Dalam perakteknya di kota Palu pemidanaan terhadap anak sudah dilakukan sesuai dengan peraturan perundang-

undangan yang berlaku dan telah mengimplemantasikan ke falsafah restoratif justice untuk mementingkan pemulihan keadaan akibat pelanggaran yang terjadi pada anak, akan tetapi secara keseluruahan belum optimal, karena peranan Hakim pengawas dan pengamat (KIMWASMAT) di Pengadilan Negeri Palu selama ini terlihat belum efektif dan belum terlihat

nyata. Padahal pengamatan dan

pengawasaan anak pidana sangat

bermanfaat bagi pembinaan dan perkembangan anak masa depan, karena dapat diketahui secara pasti tentang perkembangan yang terjadi pada anak selama proses pembinaan dan rehabilitasi di Lembaga Pembinaan Khusus Anak (LPKA) demi tercapainya perlindungan dan kesejahteraan anak. Hambatan dari berbagai segi yang menjadi alasan tidak efektifnya lembaga ini, yaitu mencakup hambatan dari

segi peraturan perundang-undangan, hambatan dari segi fasilitas dan hambatan dari segi aparat penegak hukum lainnya.

2. Sistem peradilan pidana anak saat telah menggambarkan aspek kemanfaatan karena

sudah memberikan suatu bentuk penyelasian anak melalui diversi dan restoratif justice, yang dilakukan di luar jalur pengadilan yang dilaksanakan secara musyawarah, untuk mencari solusi dan kepentingan terbaik buat anak. Selanjutnya sistem peradilan pidana anak dalam proses pemidanaan terhadap nakal tidak hanya memandang akibat yang terjadi pada masa lalu anak, tetapi memandang jauh tentang bagaimana masa depan anak nanti sebagai

generasi penerus bangsa, tanpa mengabaikan kepentingan masyarakat. Jadi, anak dapat dipidana, terutama pidana yang didalamnya menghindari penjara dengan segala perwujudannya. Pidana tersebut adalah pidana yang mengutamakan kesejahteraan dan kepentingan anak tanpa mengabaikan kepentingan masyarakat. 
Pemidanaan setelah diatur restorative justice sangat baik anak sebagai pelaku tindak pidana dimana sanksi bukanlah merupakan tujuan utama bagi pemidanaan anak karena pidana penjara merupakan upaya terakhir (ultimum remidium).

\section{B. Rekomendasi.}

1. Agar pemidanaan anak kedepannya dapat segera diambil lankah-langkah antara lain dalam hukum pidana nasional memuat ketentuan yang jelas, tegas dan berimbang mengenai pemidanaan anak atau upaya

melakukan peninjauan pembentukan kembali ketentuan hukum pidana mengenai pemidanaan anak yang sesuai dengan nilai-nilai sentralsosio-politik, sosio-filosofik, dan nilai-nilai sosio-kultural masyarakat Indonesia utamanya di Kota Palu, demi

mengurangi angka kejahatan yang dilakukan oleh anak, dan mengefektifkan tugas Hakim Pengawas dan Pengamat

khusus anak (KIMWASMAT) di Pengadilan Negeri Palu agar dapat diketahui secara pasti tentang perkembangan yang terjadi pada anak selama proses rehabilitasi di LPKA demi tercapainya perlindungan dan kesejahteraan anak.

2. Hendaknya kemanfaatan sistem peradilan pidana dalam Undang-Undang Nomor 11 tahun 2012 merupakan perbaikan dari Undang-Undang Nomor 3 tahun 1997, ini merupakan salah satu contoh bagi pembuatan undang-undang atau peraturan lain yang menyangkut mengenai anak yang harus diperhatikan bukan hanya fisik tetapi juga psikis anak, karena anak merupakan penerus bangsa sehingga harus mendapatkan bimbingan yang benar untuk proses ke depannya.

\section{DAFTAR PUSTAKA}

Arief, Barda Nawawi. 1994. Kebijakan Legeslatif dalam Penanggulangan Kejahatan dengan Pidana Penjara. Badan Penerbit Universitas Dipanegoro : Semarang.

Asquith, Stewart. 1996. Children and Young People in Comflict with the Law (ed). Jessica Kingsley Publeshers : London

Dungkel, Frieder. 2014. Juvenile Justice

System in Europe-Reform Development between Justice, Welfare, and 'New Punitiveness'. Krimilogis Studijos.

Effendi, Yazid dan Kuat Puji Prayitno. 2008. Asas-Asas Hukum Pidana. Rineka Putra : Jakarta.

Goltom, Maidin. 2013. Perlindungan Hukum Terhadap Anak dalam Sistem Peradilan Pidana Anak di Indonesia. PT. Rafika Aditama. Bandung.

King, Michael dan Christine Piper. 1995. How the Law Thinks Abaut Children. Arena Ashgate Publishing : Hants.

Moeljatno. 1993. Asas-asas Hukum Pidana. Rineka Cipta : Jakarta

Muliadi. 1985. Lembaga Pidana Bersyarat. Alumni : Bandung. 
Muladi dan Arief, Barda Nawawi. 1992. Bunga Rampai Hukum Pidana. Alumni : Bandung.

Muncie, John. 1999. Youth and Crime : A Critical Intruduction. Sage Publication : London.

Sutatiek, Sri. 2013. Rekontruksi Sistem Sanksi Dalam Hukum Pidana Anak Di Indonesia : Urgensi Penerbitan Panduan

Pemidanaan (The Sentencing Guidelines) untuk Hakim Anak. Aswaja Pressindo : Yogyakarta.

Surachman, R.M. dan Andi Hamzah. 1997. Jaksa di Berbagai Negara Peranan dan Kedudukan. Sinar Grafika : Semarang.

Soekito, Sri Widoyati Wiratmo. 1983. Anakdan Wanita Dalam Hukum. LP3S : Jakarta.

Herlina, Apong. 2014. Tanggapan Terhadap Hasil Penilitian Terkait Potensi dan Kendala Pelaksanaan Diversi dan Restorative Justice di 6 Kota di Indonesia. Makalah. 